Mali, Niger, and Nigeria on the history, culture, and religious ceremonies associated with the Niger River.

Allen F. Isaacman, Associate Professor of History and Afro-American Studies, University of Minnesota, for research in Mozambique, Malawi, and Zambia on a social and economic history of precolonial South Central Africa.

Peter H. Koehn, Assistant Professor of Political Science, University of Montana, for research in Ethiopia on the mobilization of local interests, on policy making, and on implementation under the new system of urban cooperatives.

Gayle H. Partmann, Assistant Professor of Linguistics and Sociology-Anthropology, Oakland University, for research in the Ivory Coast on the perception and social evaluation of variation in spoken French in the region of Abidjan.

David W. Robinson, Jr., Assistant Professor of History, Yale University, for research in Senegal and Mali on the talibe crusaders of the Umarian movement.

Janet L. Siskind, Associate Professor of Anthropology, Rutgers University, for research in Tanzania on the voluntary associations of Sukarma women.

Constance R. Sutton, Associate Professor of Anthropology, New York University, for research in Nigeria on Yoruba sex roles and ideology.

C. Sylvester Whitaker, Professor of Political Science, Brooklyn College, City University of New York, for research in Nigeria on the Constitutional Commission and the challenge of civil reconstruction.

\title{
RESEARCH IN AFRICA
}

The Editor

28th May 1976

African Studies Newsletter

African Studies Association

218 Shiffman Center

Brandeis University

Waltham, Mass. 02154

I am writing to solicit your assistance in publicizing the following information regarding research in Kenya.

"The Kenya Government has become very strict and thorough in scrutinising research proposals. Consequently the processing of research clearance and issue of a permit can take several months. It is important, therefore, that researchers apply well ahead of their intended arrival in Kenya. Under no circumstances should one come to Kenya before an official research permit is granted, as this might cause a heart-breaking disappointment later on.

Secondly, all those who have completed their theses should deposit a copy with the relevant authorities, as stipulated in the research permit. Failure to do so has aiready caused two individuals to be denied fresh permits. Even more, flagrant disregard of this rule will make it impossible for University departments to support future applicants, which would be a great pity.

Lastly research has been classified as 'work' in a recent immigration law. The result of this is that a fee of Ksh. 5,000 per annum is payable by foreign researchers in order to acquire a work permit."

I have taken the liberty to impose myself on you due to my anxiety over the problem of research permits. Already I have had the nasty experience of two students being turned down after coming all the way to Nairobi and exhausting their financial resources. But the situation need not get worse if individuals and institutions co-operate. We are under great pressure from the authorities to ensure that conditions stipulated in the permit are fulfilled, and yet when researchers return overseas we have no control over them.

Yours sincerely,

Dr. Godfrey Muriuki

Chairman, History Department

University of Nairobi

7th July 1976

African Studies Association

Brandeis University

Waltham, Mass. 
moment and has suggested that I write to you.

In the National Archives Library in Gaborone we try to maintain as complete a collection as possible of publications and papers relating to Botswana. These include books, articles in journals, theses, papers, and even newspaper cuttings.

When foreign research workers visit Botswana to carry out their research projects they are now required to deposit two copies of any paper they produce with the government, one of which comes to the National Archives. This seems a reasonable exchange for the facilities given them free of charge by the Botswana government.

In the past permits were not always issued and research not so well controlled and many people have come and gone without receiving a permit and depositing any material. It is of course impossible to enforce the stipulation even for those with a permit but I have found that recent research workers are very good about honouring their commitments.

I wonder if I cound appeal through your newsletter to those students who have carried out research in Botswana and not submitted copies of their work? I should be most grateful if they would send a copy of anything they produced on Botswana to the National Archives. Our library is well used both by government officers and research students from Botswana and abroad and research papers are very useful to them.

\author{
Yours sincerely, \\ J.A.V. Rose (Ms.) \\ Government Archivist \\ Botswana National Archives \\ P.O. Box 239 \\ Gaborone, Botswana
}

[It is the policy of the Board of Directors of the African Studies Association that products of research done in Africa must absolutely be sent to the appropriate agency in the host country.-The Editor]

\title{
EMPLOYMENT
}

The African Studies Newsletter regularly publishes a listing of positions open and positions wanted in African studies. Persons seeking positions will be listed anonymously, identified by a key number, with a brief description of qualifications. Letters in response to any of these numerical listings should be sent $c / 0$ the key number to the office of the Newsletter, which will forward them to the person concerned. Programs with positions open will be listed by name. Should a prospective emplover prefer to remain anonymous, however, we shall be glad to put simply a key number and a description in the Newsletter, and use the correspondence procedure described above.

\author{
Rates are as follows: \\ Members of the Association-one free listing per year \\ (additional listings at the non-member rate) \\ Non-members of the Association-\$5.00 per listing \\ Institutions $\$ 10.00$ per listing
}

\section{POSITIONS WANTED}

76-5 Johannesburg (Soweto) Attorney at Law (10 years) seeks position as Assistant Professor in Anthropology, African Studies, or Black Studies. B.A. Sociology and African Administration (South Africa); M.A. Anthropology (Northwestern); Diploma in Social Work (South Africa). Former Minister of Interior and Economic Affairs of Lebowa. Special Fields: African Cultures, History and Legal Systems; African Literature, Politics, Economics; African Diaspora. Fieldwork among the Pedi, Venda, and Tsonga of northern Transvaal.

76-6 Position sought by Political Scientist with six years' teaching and research experience in the U.S. and Africa, including field research in Tanzania and Zambia and university teaching and program chairmanship in Zambia. Competencies: African Politics; Political Economy of Underdevelopment; African Local Politics; Comparative Politics; Law and Development. Geographic specialization: East, Central, and Southern Africa. Languages: French, Swahili. Publications: book, edited book, articles. Available 1977.

76-7 Art Historian, Ph.D.; several years of study and work in sub-Saharan Africa; publications. Seventeen years of college and university teaching; academic administrative experience. Available fall 1976. 